Copyright (C) 2018 by Academic Publishing House Researcher

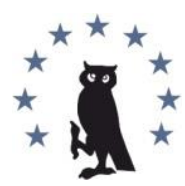

Published in the Russian Federation

European Researcher. Series A

Has been issued since 2010.

ISSN 2219-8229

E-ISSN 2224-0136

2018, 9(2): 113-120

DOI: $10.13187 /$ er.2018.2.113

www.erjournal.ru

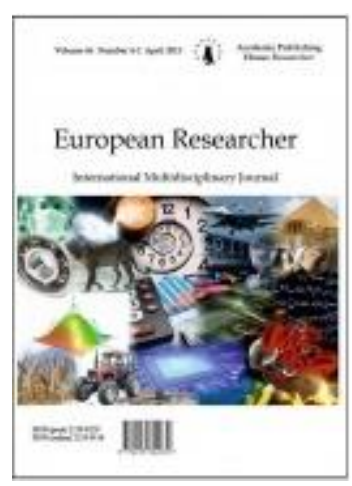

\title{
Comparison of Aggressiveness among Groups of Sportsmen According to Selected Types of Sports
}

\author{
Mária Gregáňová a , * \\ ${ }^{a}$ Matej Bel University, Banská Bystrica, Slovakia
}

\begin{abstract}
The aim of the research was to find out the different types of aggressiveness among sportsmen performing individual sports and then compare the results obtained among selected types of sports. The theoretical analysis of the aggressiveness issue was carried out on the basis of a literature study, which is also based on an empirical research.

A standardized psychological questionnaire B - D - I, aimed at diagnosing aggression, was used to obtain the factual material.

We analyse and compare the values obtained on the basis of the psychological questionnaire B - D - I and interpret the results obtained. For better clarity, we provide measured values in the form of tables and figures.

In the subtest irritability the highest initial measurements (IM) were reached in the value 9,1 which indicates significant rise of the level of the given type of aggressiveness. One respondent belonging to the file B (cross-country skiing) and one respondent from the file D (fitness and body building) have this high extent of irritability.

By testing the level of negativism and subsequent comparison of the median values between individual sets, we have achieved results that point to the dominant occurrence of this type of aggressiveness in the file $\mathrm{C}$ (cycling).

The analysis of the results related to the occurrence of the level of resentment in the individual examined files showed the highest IM rate of 8.75. Such IM values were measured in two sets, namely in the group B (cross-country skiing) and D (fitness and bodybuilding).

Keywords: emotions, sports psychology, aggressiveness, aggressivness in sport, individual sports.

\section{Introduction}

Authors Jandourek (2001), Škodáček-Černovský (2004), Martinek (2009) and Dobrôtka (1999) agree that word aggression is derived from latin word "agreddi" meaning to ensure one's access, to attack, to dare, try to overcome somebody. Anderson - Bushman (2002) and David Tod (2010) emphasize fact that aggressive behaviour is in the first place behaviour not attitude or even emotions.

We agree with the opinion that aggression is certain characteristic, perosnality trait. Definition of aggression says it is an unpleasant activity against other person. According to three basic theories aggression can be understood as an instinct (S. Freud, K. Lorencz), as an acquired

\footnotetext{
${ }^{*}$ Corresponding author

E-mail addresses: maria.greganova@umb.sk (M. Gregáňová)
} 
characteristic (A. Bandura) or as a bio-psycho-socially conditioned entity (Kariková, 2001; Pavlovský 2009; Harsa et al., 2012).

Hart-Hartlová (2004) and Výrost-Slaměník (2008) define term aggression as follows: "aggression is an offensive or belligerent action, hostility expression against certain object, intentional attack on obstacle, person or object that stands in the way of satisfying one's need (response to frustration).

"aggression is habituated way of behaviour with tendency to react by long term attacking, hostile focus with high promptness to aggression" (Hanušková, 2008: 68)

Vágnerová (2004) and Výrost-Slaměník (2008) agree that aggression is a tendency to make aggressive act, to behave aggressively, it is the tendency to hurt intentionally.

Heretik (2000) distinguishes altruistic, hostile, social and verbal aggression.

On the other hand authors Výrost-Slaměník (2008) distinguish affective aggression, instrumental aggression and bullying (tyranny). The other point of view on distinguishing aggression has Blahutková (2011). She distinguishes altruistic, anticipating, instrumental, inductive and shifted aggression.

Other authors such as Burk-Durkee (1957) worked on the assumption that aggression is the complex phenomenon for which is suitable to distinguish some subcategories of hostile aggressive behaviour. They made 8 categories (items) considering them basic aggression subcategories: assault, indirect hostility, irritability, negativism, resentment, suspicion, verbal hostility and sense of guilt (Buss-Durkee, 1957).

The personality influence on sports performance belongs to greatly discussed subjects. On the one hand there are skeptics that do not admit relationship between personality and sports performance and on the other hand are those who consider personality influence for significant factor of sports activity successfulness (Silva-Stevens, 2002).

According to the Hošek (2005) the most important base of knowing athlete's personality is developmental attitude. This attitude lies in respecting the fact that athlete's personality is determined by long-term influence of three groups of factors: atheletes' inborn anatomyphysiological presuppositions; presports, sports and outsports environment; socially-educational influence (social learning):

- nonsystematic individual learning by immitation;

- institucional systematic upbringing and performance development.

According to Slepička (2006) sports activity is characterized by strong emotionality given by loaded and at the same time attractive sport programme.

Vanek (1984) and Nakonečný (2000) think that emotions at the same time influence also other mental processes as perception, imagination, thinking, memory, focus and free processes. Emotions influence sports activity by certain intensity and quality. Experience intensity relates to level of athletes' activation.

Optimal performance as Tod, Thatcher and Rahman (2012) mention comes when athlete experience adequate activation level and performance is bad or activation is either high or low.

According to Jarvis (1999) and Kunath (2001) theories of instincts suggest that sport serves for actual decreasing of aggressiveness in society in a way that enables expression of our aggressive instincts.

Fleming (2008) distinguishes three acceptable and one nonacceptable form of agression in ice hockey: tactic violance, symbolic violance, actual violance and violance with intension to heavily hurt and harm opponent - it is a form of aggression that results in grevious bodily harm.

Lauer-Paiement (2009) tell about higher rate of aggression in a game that is alarming not only for a danger of many serious healh problems that has arisen e. g. as a result of the frequent head shocks, but there is a concern that aggressive behaviour can transfer to other situations too.

\section{Aim}

Aim of the research is to compare the level of aggressiveness among individual groups of sportsmen according to the sort of conducted sport. 


\section{Methodology}

We were detecting the level of aggressiveness among sportsman who efficiently perform athletics, cycling, cross-country skiing and fitness, where each of chosen sports was represented by 8 probands. The criterion of inclusion to our research was fully organised training with min. 4 raining units per week and participation in at least one of championship events of national or international character (Slovak championship, world Championship, Olympic Games) which means that our selection was stratified. The research file was created by 32 respondents, thereof 11 women and 20 men were tested. The age range of respondents was ranged within the range from 19 to 33 years.

The group of athletes was created by 8 racers representing different Slovak clubs, specifically Akademik TU Košice, Spartak Dubnica, Slávia Trnava, Slávia UK Bratislava a ŠK UMB Banská Bystrica. From this group, 5 women and 3 men were tested, by age ranging from 19 to 33 years. Athletes in the set competed in the long jump, triple jump, pole vault, flat race and obstacle race. The set of cross-country skiers was created by 8 respondent who race for the cross-country club Sky Team Jase Látky, there were 2 women and 6 men by age ranging 20 to 27 years.

We placed racers of the club CK Banská Bystrica to the group of cyclists where this research file was created by 7 men and 2 women in age ranging within 23 to 32 years.

The last examined file were sportsmen performing competitive fitness, bikini fitness,classic bodybuilding and power triathlon, who are members of the union SAKFST. Concerned group as created by 8 respondents as well, consisting of 4 women and 4 men in age ranging within 24 to 29 years.

From the point of view data processing we created individual files from mentioned probands, which we marked by letters as follows:

$$
\begin{aligned}
& \text { A - athletics (men + women) } \\
& \text { B - cross-country skiing (men + women) } \\
& \text { C - cycling (men + women) } \\
& \text { D - fitness and body building (men + women) }
\end{aligned}
$$

The research was conducted within months april 2015 ad may 2015, where 32 of 35 distributed questionnaires were returned which we subsequently used for research purposes. Administration of psychology questionnaires among the group of cross-country skiers and cyclists was conducted in groups, after absolving their training. With the group of sportsmen performing fitness and body building we accomplished individual testing in the sports town hall in Hnúšta, and that after Slovak championship in bodybuilding and junior fitness.

The research was organized with the help of standardized psychological questionnaire B - D - I, which was created by authors Buss - Durkee (1957) and is aimed to aggressiveness diagnosing. The classification of this test includes 2 types of hostility (resentment and shadiness) and 5 types of aggressiveness (physical, indirect, verbal, irritability and negativism).

First, we processed obtained data by counting positive responses among each respondent individually, thanks to what we reached gross score. Agreeable answers were subsequently sorted and assigned to individual subgroups to which they belong from the point of view of the examined phenomenon. The research method used by us predetermines each subgroup certain coefficient used to evaluate (from 0,77 to 2), where by its multiplication with the gross score we reach the weighted score.

The values of the weighted score excessing in some of individual subtests the volume 5 , mean increased level of a respective type of aggressiveness. In our measurement we recorded the values from o to 9,1 which in the first case indicates the appearance of zero value, in the second case significantly increased value of the given type of aggressive behaviour.

The evaluation of responses of probands performing individual sports was realised according to the key:

- Kruskal-Wallis test - aimed to the detection of the significance of differences in medians between groups, which is non-parametric alternative ANOVI as single-factor analysis of the dispersion, which expects normality of division. The advantage of ordinal analysis of the dispersion rests in the fact that we do not have to examine the normality of the dispersion. That is why the non-parametric version is applicable on much wider circuit of research problems, on the base of which we considered suitability of its use also for our research problem (Brod'áni, 2012). 


\section{Results}

Leaning on the results obtained by examining the questionnaire B-D-I we conducted frequency analysis of the occurrence of all score cathegories in various types of individual sports, which we subsequently compared to one another.

By comparing medians obtained within subtest physical aggressiveness we found out that the file $\mathrm{D}$, which is represented by sportsmen from the field of fitness and body building, tends most significantly within subtest physical aggressiveness. The relevant group with measured median value 7,5 also as the only one exceeds reasonable level of physical aggressiveness.

The score recorded among other files does not indicate increased level of a given type of aggressiveness. The lowest median in the value of 1,5 was measured in the file A (athletics).

\section{Median - Physical aggressiveness}

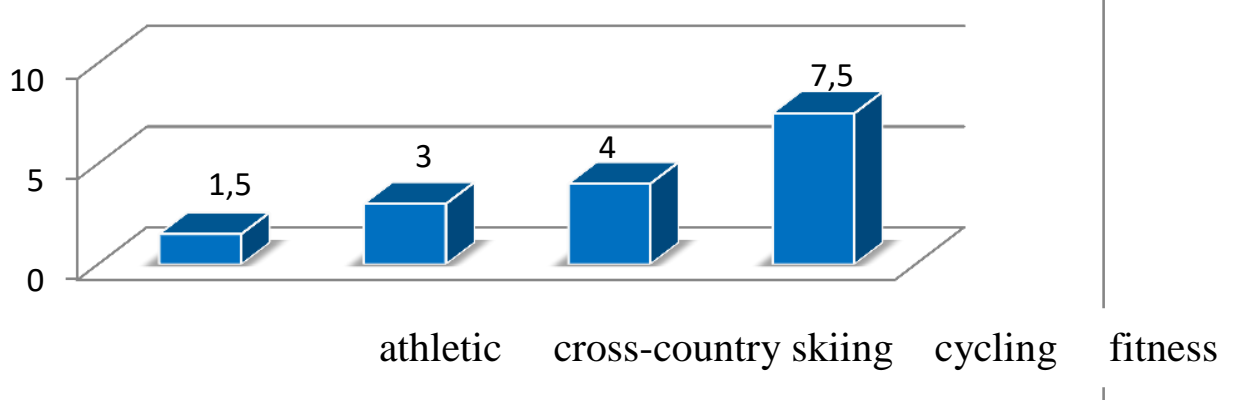

Fig. 1 The ratio of the subtest Physical aggressiveness values

In the subtest irritability the highest initial measurements (IM) were reached in the value 9,1 which indicates significant rise of the level of the given type of aggressiveness. One respondent belonging to the file B (cross-country skiing) and one respondent from the file D (fitness and body building) have this high extent of irritability. The $\mathrm{IM}=\mathrm{O}$ were recorded only in one case and that was a sportsman representing group A (athletics). As we can see, the values IM indicating increased measure of irritability only one third of the complete amount of tested sportsmen reached.

We assume that such result will be influenced mainly by the individual character of a sport activity which our sportsmen perform. Manifestations of affective aggressiveness therefore can be mostly observed in the field of collective sports allowing mutual contact of sportsmen (football, basketball, handball, hockey, etc.), where the very nature of sport anticipates this form of aggressive behaviour.

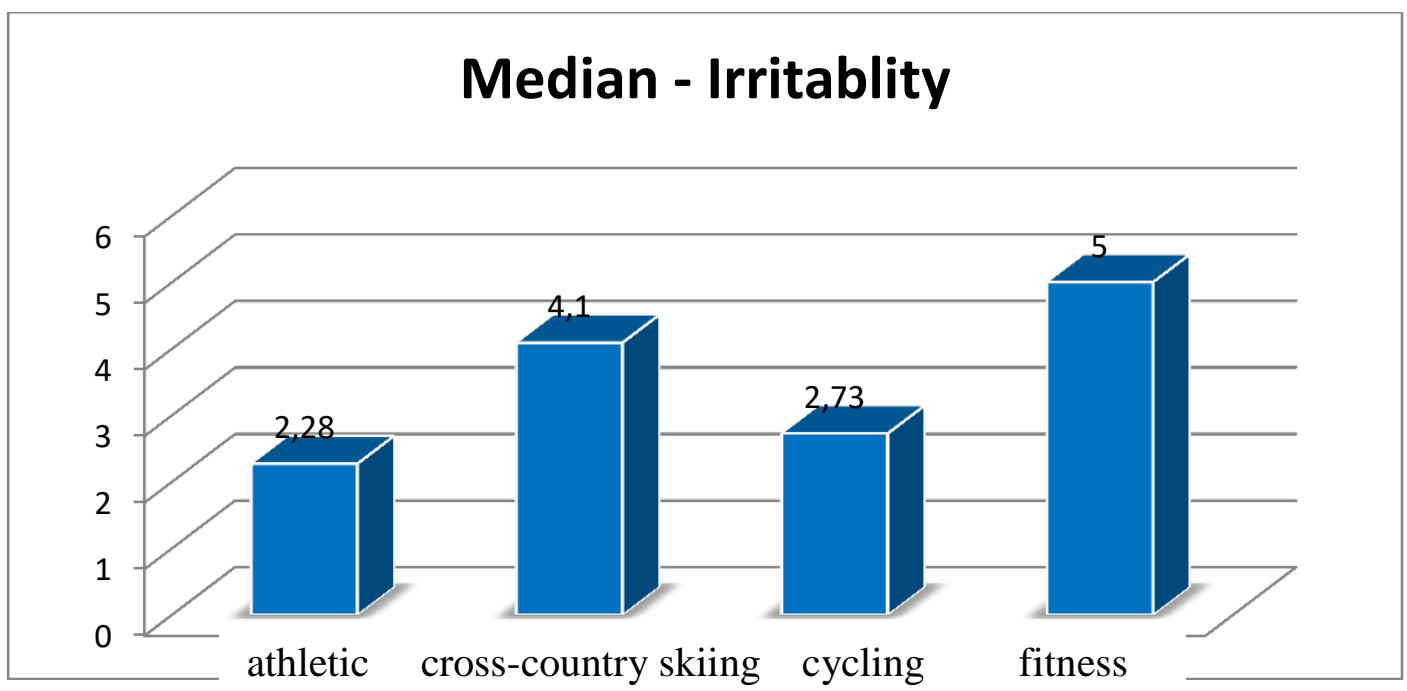

Fig. 2. The ratio of the subtest Irritability median values 
By testing the level of negativism and subsequent comparison of the median values between individual sets, we have achieved results that point to the dominant occurrence of this type of aggressiveness in the file $\mathrm{C}$ (cycling). The appropriate set of measured median values of 6 , at the same time, exceeded the appropriate values in this scoring category. For the other groups tested, values indicating an increased level of negativity were not recorded. The highest measured IM was 8, in both group B (cross-country skiing) and D (fitness and bodybuilding) and up to three in the group $\mathrm{C}$ (cycling). The minimum IM = $\mathrm{O}$ was found in the file $\mathrm{A}$ (athletics) and in the file $\mathrm{B}$.

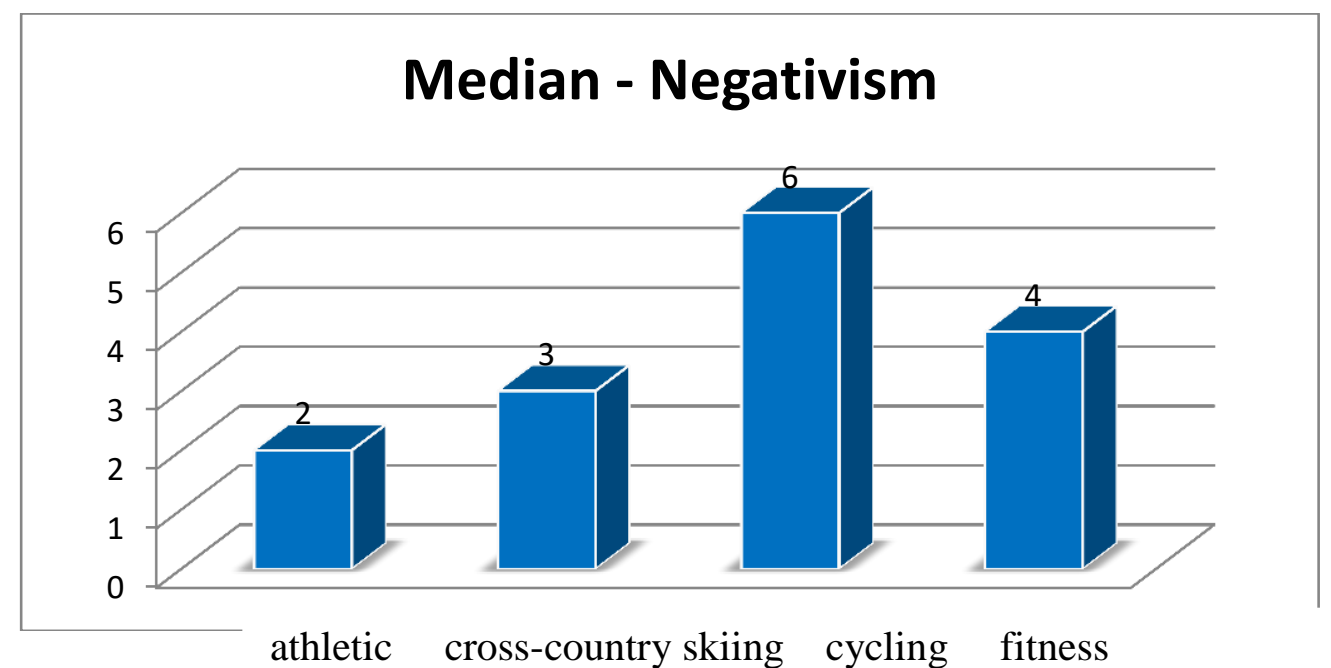

Fig. 3. The ratio of the subtest Negativism median values

The analysis of the results related to the occurrence of the level of resentment in the individual examined files showed the highest IM rate of 8.75. Such IM values were measured in two sets, namely in the group B (cross-country skiing) and D (fitness and bodybuilding). In file B, there was an increased resentment rate in total only for two probands who significantly exceeded the other members of the group in the achieved IM values.

The most significant tendency to feel injustice, to envy happiness and success of other people is found in D (fitness and bodybuilding). At the same time, this set as the only one tested exceeded the median of 5 , which means that the level of aggressiveness was higher only for the sportsmen focused on fitness and bodybuilding. The second highest score was in the group A (athletics) at 3.75. The remaining two sets achieved the same results in the corresponding scoring category, where the median was 1.88 .

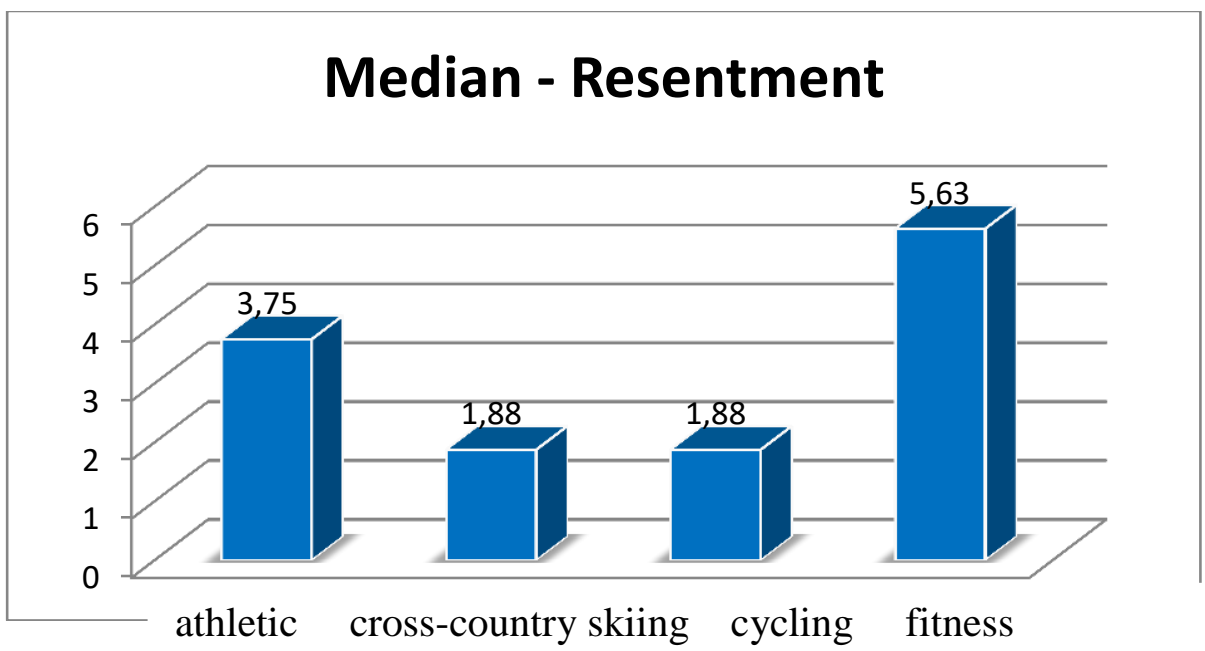

Fig. 4. The ratio of the Resentment subtest median values 


\section{Discussion}

Based on the results obtained by evaluating the B-D-I questionnaire, we performed a frequency analysis of the occurrence of the scoring categories in individual types of individual sports, which we subsequently compared to one another.

Based on the calculated median values in all 8 subtests among the selected files, we recorded the highest score achieved in the category of physical aggression, namely the group D (fitness and bodybuilding). Another category in which we measured values exceeding a reasonable degree of aggressiveness is indirect aggressiveness, namely in groups B, C, D. Increased negativism was recorded in the group $\mathrm{C}$ and resentment, along with a sense of guilt in the group $\mathrm{D}$. The files examined by us represent sports where due to their individual character an increased level of aggression is not expected.

However, as Slepička - Hošek - Hátlová (2009) assume, it is possible to show direct physical aggression in this area, especially in the effort to achieve the best position. A typical example is the attitude of a positional fight of athletes in the final finishing, which we can often encounter in such sporting areas as cycling or cross-country disciplines.

In his study, Lovaš (2010) draws attention to the importance of the impact of biochemical processes, as the presence of certain substances in the blood significantly increasing human sensitivity to an aggressive stimulation. It emphasizes the influence of male hormone testosterone, whose elevated blood level may be one of the causes of a high level of aggressiveness. He also adds that the biochemical process, which is largely influenced by the level of aggressiveness, is also low in blood sugar and decreased serotonin metabolism. (Lovaš, 2010).

There is no news that an intensive physical load increases the growth of hormone production of testosterone which is the living proof of bodybuilders, weightlifters, or racers in the power triathlon. We also know that many athletes in this area use the so-called carbohydrate waves which means they work with a constantly changing intake of carbohydrate in the diet. These facts could help explain the cause of the increased level of physical aggressiveness found in the group D and therefore among athletes performing fitness and bodybuilding. The results of the Kruskal-Wallis test show that differences in median values in the relevant category are statistically significant $(p=$ 0.0243) which means that the extent of the occurrence and the nature of physical aggressiveness will indeed depend on the type of sport practiced.

In the irritability subtest, the highest IM was achieved at 9.1, indicating a significant increase in the level of the type of aggressiveness. Such a high level of irritability has one respondent belonging to the file B (cross-country skiing), and one respondent from the file D (fitness and bodybuilding). We recorded $\mathrm{IM}=\mathrm{O}$ only in one case, with the athlete representing the group $\mathrm{A}$ (athletics).

However, according to Gregor (2013), aggressiveness in sport may range from a high activity to brutality, highlighting the importance of maintaining increased personal engagement within the limits of sporting rules and ethical standards. Research in this area has shown the most proved the most significant representation of respondents inclined to negativity in the file $\mathrm{C}$ (cycling) where up to half of those tested have reached values leading to an increased tendency to refuse authority.

Since it is a type of aggressiveness that does not always manifest itself externally, we will agree with Gregor (2013), who claims that aggressiveness is a personality characteristic that can be negatively understood from the point of view of ethics, therefore not everybody is willing to confess it voluntarily. From the point of view of psychodiagnostics, it is therefore difficult to clearly diagnose aggressiveness in a person's personality. (Gregor, 2013)

The analysis of the results related to the occurrence of the level of resentment in the individual files examined showed the highest IM rate of 8.75. Such IM values were measured in two sets, namely in the group B (cross-country skiing) and D (fitness and bodybuilding). In file B, there was an increased resentment rate in total only for two probands who significantly exceeded the other members of the group in the achieved IM values.

The differences between the types of sport are statistically significant due to overall aggression. Therefore, we will agree with the group of authors Vanek - Hošek - Svoboda who in their study point to the fact that personal differences between athletes of various sports sectors are often very significant (Vanek et al., 2009). 


\section{Conclusion}

We were able to fulfil the aim of the research which we set with the help of properly chosen method of standardized psychological questionnaire B - D - I and it subsequent analysis

The highest IM scores we scored through the subtests are in the Irritability category with a fitness and bodybuilding sportsman. The weighted score for this respondent was 9.1, indicating a tendency for this sportsman to react violently even with little irritation, impatience with other people or overall irritability.

The lowest weighted values that represent the zero weighted score occurred in several of the relevant subtests. These were found in the category Negativism. These were specifically three of the sportsmen and two in the group of cross-country skiers. The Resentment subtest showed zero IM for cyclists.

Physical aggression with zero IM values occurred in two cases in the skiing group and one in the group of sportsmen. Since zero values mean the absence of the kind of aggression in the sportsman's personality and therefore the sportsman does not undermine the behaviour characteristic for each kind of aggressiveness, we can say that it is a relatively positive phenomenon.

For sports practice, we recommend the trainer's attention to be focused on a sportsman's mental state, not just the goal, and to include training elements for psycho-hygiene in training.

\section{References}

Anderson, Bushman, 2002 - Anderson, C. A., Bushman, B.J. (2002). Humanaggresion. Manual review of psychology, vol. 12, no. 9, p. 53.

Blahutková, 2011 - Blahutková, M. (2011). Rodinné prostředí a výkon ve sportu u dětí a mládeže. In Asociace psychologů sportu. Psychologie sportu v praxi 2011. první. Praha: Filozofická fakulta UK Praha, pp. 112-119, p. 8.

Buss, Durkee, 1957 - Buss, A. H., Durkee, A. (1957). Aninventory for assessing different kinds of hostility. vyd. Jurnal of Consulting Psychology, 1957. 21 p.

Fleming, 2008 - Fleming, S. (2008). Towards a Theoretical Understanding Of Violence In Ice Hockey. International Journal of Violence and School, pp. 118-128.

Gee, Leith, 2007 - Gee, CH. J., Leith, L. M. (2007). Aggressive behavior In professional ice hockey: A cross-cultural comparison of North American and European born NHL players. Psychology of Sport and Exercise. vol. 8, no. 4, pp. 567-583.

Gregor, 2009 - Gregor, T. (2009). Porovnanie osobnostných a motivačných charakteristík zjazdových lyžiarov a nešportovcov. In Telesná výchova a šport. roč. 19, č. 1, p. 38.

Gregor, 2013 - Gregor, T. (2013). Psychológia športu. Bratislava: Mauro Slovakia, 400 p.

Hanušková, 2008 - Hanušková, V. (2008). Terapie akutního neklidu a agrese. Psychiatrie pro praxi. vol. 9, no. 4, pp. 168-169.

Harsa et al., 2012 - Harsa, P., Kertézsová, D., Macák, M., Voldřichová, I., Žukov, I. (2012). Současné projevy agrese In Psychiatrie pro praxi. roč. 13, č. 1, pp. 15-18.

Hartl, Hartlová, 2004 - Hartl, P., Hartlová, H. (2004). Psychologický slovník. Praha: Portál, $774 \mathrm{p}$.

Heretik, 2000 - Heretik, A. (2000). Forenzná psychológia pre psychológov, právnikov, lekárov a iné pomáhajúce profesie. Bratislava : Eurokódex, 554 p.

Hodůrová, 2011 - Hodůrová, B. (2011). Agresivita trenérů různých sportovních skupin. Diplomová práce, Olomouc: Filozofická fakulta.

Jandourek, 2001 - Jandourek, J. (2001). Sociologický slovník. Praha: Portál, 288 p.

Jarvis, 1999 - Jarvis, M. (1999). Sport Psychology (Routledge Modular Psychology). London: Taylor \& Francis, 158 p.

Kampmiller, 2010 - Kampmiller, T. et. al. (2010). Základy metodológie výskumu v telesnej výchove a športe. Vyd. Bratislava: ICM agency, $192 \mathrm{p}$.

Kariková, 2001 - Kariková, S. (2001). Základy patopsychológie detí a mládeže. Banská Bystrica: PF UMB, 166 p.

Keller, 2007 - Keller, A.L. (2007). The Differences in Sport Aggression, Life Aggression, and Life Assertion Aminy Adult Male and Female Collision, Contact, and Non-Contact Sport Athletes In Journal of Sport Behavior. vol. 30, no. 1, pp. 57-76. 
Končeková, 2010 - Končeková, L. (2010). Vývinová psychológia. 3. vyd. Prešov: Vydavatel'stvo Michala Vaška, 312 p.

Kunath, 2001 - Kunath, P. (2001). Sportpsychologie fur alle. Aachen : Meyer und Meyer, $125 \mathrm{p}$.

Langmeier, Krejčírová, 1998 - Langmeier, J., Krejčířová, D. (1998). Vývojová psychologie. 3. vyd. Praha: GradaPublishing, 343 p.

Lauer, Paiement, 2009 - Lauer, L., Paiement, C. (2009). The Playing Tough and Clean Hockey Program. The Sport Psychologist : Human Kinetics, Inc. 2009. vol. 8, no. 4, pp. 543-561.

Lenzi et al., 1997 - Lenzi, A., Bianco, I., Milazzo, V. et al. (1997). Comparison of aggressive behavior between men and women in sport. Perceptual and motor skill, vol. 84, no 1, pp. 139-145.

Lovaš, 2010 - Lovaš, L. (2010). Agresia a násilie. Bratislava: Ikar, 2010. 197 p.

Martínek, 2009 - Martínek, Z. (2009). Agresivita a kriminalita školní mládeže. Praha: Grada Publishing, a. s., 152 p.

Nakonečný, 2000 - Nakonečný, M. (2000). Lidské emoce. Praha: Academia.

Pašková, 2005 - Pašková, L. (2005). Pohl’ad na výkonovú motiváciu v kontexte „Big Five“ prostredníctvom faktorovej analýzy. In Zborník abstraktov konferencie: „Sociální procesy a osobnost 2005“. Správy: Psychologický ústav AV ČR. Brno 22.9-23. 9. p. 12.

Pavlovský a kol. 2009 - Pavlovský, P. a kol. (2009). Soudní psychiatrie a psychologie. Praha: Grada Publishing, a. s. , 226 p.

Silva, Stevens, 2002 - Silva, J. M., Stevens, D. E. (2002). Psychological foundations of sport. Boston: Allyn \& Bacon. 664 p.

Slepička a kol. 2006 - Slepička, P. a kol. (2006). Psychologie sportu. Praha: Nakladatelství Karolinum, Univerzita Karlova, 2006. 230 p.

Slepička et al., 2009 - Slepička, P., Hošek, V., Hátlová, B. (2009). Psychologie sportu. Praha: Univerzita Karlova v Praze, 240 p.

Šafár̆, 2003 - Šafár̆, M. (2003). Komparace agresivity ve vybraných sportovních skupinách. Disertační práce: Olomouc.

Škodáček, Černovský, 2004 - Škodáček, I., Černovský, K. (2004). Symptómy agresivity v osobnosti mladistvých In Psychiatria. roč. 11, č. 2, pp. 65-69.

Tod et al., 2012 - Tod, D., Thatcher, J., Rahman, R. (2012). Psychologie sportu (1. vyd.). Praha: Grada, 200 p.

Tod, 2010 - Tod, D. (2010). Psychologie sportu. Praha: Grada Publishing, 2010. 200 p.

Vágnerová, 2004 - Vágnerová, M. (2004). Psychopatologie pro pomáhající profese: variabilita a patologie lidské psychiky (1.vyd.). Praha : Portál, 1999. 448 p.

Vaněk et al., 1984 - Vaněk, M. et al. (1984). Psychologie sportu: rozbor psychických složek sportovního výkonu (1. vyd.). Praha: Olympia, 288 p.

Výrost, Slaměník, 2008 - Výrost, J., Slaměník, I. (2008). Sociální psychologie. Praha: ČR: Grada Publishing, a.s. 404 p. 